\title{
Effect of Guided Imagery on Depression in Male Inmates
}

(Kesan Imageri Berpandu pada Kemurungan dalam Kalangan Banduan Lelaki)

\author{
ENDEH NURGIWIATI* \& MAMAT RAHMAT
}

\begin{abstract}
The study was a Quasi experimental two group pre-and post-experimental design. It involved 32 samples at both experimental and control groups. This research was conducted to examine the effect of Guided Imagery on depression among male inmates. Subjects in the experimental group were asked to practice Guided Imagery in group for 10 sessions three times a week over 4 weeks of treatment period. Subjects from the control group participated in daily activities. Due to ethical consideration, following the completion of this study, however, the subjects in the control group were given Guided Imagery exercises as to reduce their depression signs and symptoms. The data were collected from the prisoners at Correctional Institution Sukamiskin Bandung Indonesia, from August to September 2014. Guided Imagery demonstrated a statistically significant reduction in depression $(\mathrm{p}=0.041)$ on the experimental group compared with the control group. Guided Imagery is a powerful, simple and economic intervention to reduce depression symptoms. The study found that the experimental group experience less depression than the control group. This study can be applied to other correctional institutions to reduce depression among prison inmates. Further studies are recommended to explore the effectiveness of guided imagery on depression among male inmates.
\end{abstract}

Keywords: Depression; Guided Imagery; male inmate

ABSTRAK

Kajian ini adalah uji kaji Quasi dua kumpulan sebelum dan selepas reka bentuk eksperimen melibatkan 32 sampel dalam kedua-dua kumpulan eksperimen dan kawalan. Kajian ini dijalankan untuk mengkaji kesan Imageri Berpandu pada kemurungan dalam kalangan banduan lelaki. Sampel dalam kumpulan eksperimen diminta mengamalkan Imageri Berpandu selama 10 sesi tiga kali seminggu selama 4 minggu tempoh rawatan. Sampel daripada kumpulan kawalan menyertai aktiviti harian. Oleh kerana pertimbangan etika, selepas selesai kajian ini, sampel dalam kumpulan kawalan diberi latihan Imaginasi Berpandu untuk mengurangkan tanda dan gejala kemurungan mereka. Data telah dikumpulkan daripada banduan di Institusi Pemasyarakatan Sukamiskin Bandung Indonesia, dari Ogos hingga September 2014. Imaginasi Berpandu menunjukkan pengurangan ketara secara statistik ( $\mathrm{p}=0.041)$ pada kumpulan eksperimen berbanding dengan kumpulan kawalan. Imaginasi Berpandu adalah campur tangan yang berkuasa, mudah dan ekonomi untuk mengurangkan gejala kemurungan. Kajian ini mendapati bahawa kumpulan eksperimen mengalami kurang kemurungan berbanding kumpulan kawalan. Kajian ini juga boleh digunakan oleh institusi pemulihan lain untuk mengurangkan kemurungan dalam kalangan banduan penjara. Kajian lanjutan adalah dicadangkan untuk mengkaji keberkesanan Imaginasi Berpandu pada kemurungan dalam kalangan banduan lelaki.

Kata kunci: Banduan lelaki; Imageri Berpandu; kemurungan

\section{INTRODUCTION}

Corruption is a serious problem in the Asian countries that 19 out of $26(73.1 \%)$ countries have high level of Perceived Corruption Index (PCI) below 50/100 except, Singapore, Hong Kong, Japan, Bhutan, Taiwan, South Korea and Brunei (Quah 2011). In Indonesia corruption is a critical problem and should be eradicated by the government. This was indicated by a CPI of about 32/100 (Dick \& Butt 2013). Corruption from the criminological perspective is a result of interaction between individual and situational factors (Huisman \& VandeWalle 2010). The individual factors related to an act of corruption are values, motivation and personal norms. Meanwhile, the situational factors are social norms, economic condition and opportunities. These were in line with studies stated that people who hold a strong egoistic values are lack of personal norm, and driven by the economic condition while living in a non-strict corruption regulation area are more prone to conduct corruption (Dong et al. 2012; Tavit 2010).

In European Union country, corruption occurs at several areas either in public institution or private sector. In public institution, corruption began from top to bottom level such as minister, judges, politician (members of Parliament), police officer, customs officer and in private sector including lawyer, accountants, doctors and surveyors (Directorate General Justice, Freedom, and Security 2010).

In Indonesia corruption is predominantly committed by public figures such as businessmen, public or government 
officers and members of parliament. The corruptors are punished and placed into prisons such as correctional institution centers.

Life as an inmate experienced by corruptors may have psycho-social impacts such as loss of freedom, autonomy, self esteem, comfort, employment, significant person and changes of social activities and environment. Social isolation experienced by prison inmates is a major factor influencing their adaptation process during incarceration. This is especially for prisoners who get infrequent visits from family and friends, which leads to maladaptive behavior, for instance violence, aggression, anxiety and depression (Dye 2010). This condition may develop into mental health disturbances.

The World Health Organization (Math et al. 2011), stated that one million out of nine million of prisoners around the world suffer from anxiety and depression. Moreover, an Australian investigation reported that the incidence of depression among inmates was the primary cause for admission for $15.4 \%$ of women and $7.8 \%$ of men (Alan et al. 2011). Depression is characterized by negativity toward future imagery (Morena et al.2011). Signs and symptoms of depression includes emotional disturbances such as sadness, hopelessness, pessimism, loss of interest in activities, difficulty in concentration and decision making as well as fatigue, sleep disturbances and loss of appetite.

Prisoners need assistance in dealing with their problems related to their being jailed including how to cope with separation from loved ones, how to adapt to prison as their home for short or long periods. They should also learn how to survive and cope with the psychological and physical demands or challenges of daily life in the prison environment (Weiten et al. 2011).

Pharmacological treatment to reduce inmate depression symptoms resulted in side effects or addiction. On a contrary, non pharmacological treatments have advantages such as chief and easy efficient administration. Psychosocial intervention such as non pharmacological treatments were given to the inmates including group and individual cognitive behavior therapy (CBT), group interpersonal therapy, Iyengar yoga and art therapy (Hughes 2012).

Mental imagery or visualization is the experience of perception without real sensory input. It is a powerful driver of emotion in maintaining and modifying threats and treating emotional symptoms and other psychological disorders (Heyes et al. 2013; Holmes \& Mathew 2010). Guided Imagery or visualization is a cognitive- behavioral meditation technique in which the individual is guided to imagine a relaxing scene or series of experiences involving sensory responses such as sight, sound, smell, touch and taste. In Guided Imagery, an individual visualizes and imagines a scene and react as if they are actually present at the scene. Several studies reported by Blackwell and Holmes (2010) that this imagery decreased depression symptoms. Another study by Lin et al. (2010) stated that Guided Imagery can reduce depression. Moreover Guided Imagery increased positive effects and enhanced performance on task behavior (Pictet et al. 2011).
Early investigations at Correctional Institution Class I Sukamiskin Bandung Indonesia for prisoners found guilty of corruption showed the incidence rate of depression was $50 \%$ ranging from mild to moderate depression, especially in the first three months of incarceration. Therefore, health care providers treated symptoms of depression with pharmacological and spiritual strategies, but psychological treatment was not administered to reduce depression among these prisoners. Although Guided Imagery was known to be able to reduce depression, it can modify negative cognition and improve the emotional state of depression. It has many benefits such as inexpensive, simple and able to reduce anti depression medication usage. Moreover, no studies had examined the effect of Guided Imagery on depression among prisoners. Consequently, this study was conducted to reduce depression among prisoners in correctional institution class I Sukamiskin Bandung Indonesia.

The purpose of this study was to find ways to reduce depression among inmates. This study hypothesizes that subjects who receive Guided Imagery would show greater improvement in depression than subjects who did not receive Guided Imagery treatment.

\section{METHOD}

\section{DESIGN AND SELECTION OF SUBJECTS}

The Quasi Experimental study was chosen to measure the differences of depression level between the experimental group who received Guided Imagery treatment and the control group who received no treatment. The inclusive criteria for selecting subjects were prison inmates who have lived in the correctional institution for at least 6 months. Moreover, the subjects had finished the adaptation and adjustment processes to prison life, had no hearing impairment, cognitive impairment and were willing to participate in Guided Imagery treatment on regular basis for 10 sessions. Exclusion criteria were chronic physical illnesses. The sample size of the subjects was determined and it had a level significance of 0.05 .

Initially, there were 64 subjects who participated in the study. However, there were 32 subjects who withdrawn from the study due to their physical condition and their involvement in another justice process. Therefore, the remaining participants were 32 subject consisted of 16 subjects in experimental group and 16 subjects in control groups.

\section{MEASUREMENT}

Beck Depression Inventory/BDI (Beck et al. 1988) was self-administered in both groups as a pre- test to obtain depression signs and symptoms. This consisted of 21 Likert items ranging from 0-3on a numeric rating scale measuring psychological and physical aspects from signs and symptoms of depression. The Cronbach's alpha of this instrument was 0.86 and was translated into Bahasa Indonesia. 


\section{STUDY PROCEDURE}

This study was approved by the Ethical Committee of Health Research Bandung Polytechnic Ministry of Health Indonesia No: LB.02.1/3.1/2099.3/2014 and was undertaken with permission from the West Java Province Head Office, Ministry of Law and Human Rights, No W11. HM.05.04-/975 and the Head of Correctional Institution Class I Sukamiskin Bandung. All subjects were contacted, explained about the purpose of the study and asked to participate voluntarily and sign a form of anonymity informed consent. The subjects were free to refuse and withdraw from this study. Subjects from both groups were asked to self-administered of their depression signs and symptoms as pre-test and the result was recorded.

Subjects from the control group involved in routine such as a class for reading the Holy Book (Al Quran), jogging and reading in the library. Due to ethical consideration, following the completion of this study, however, the subjects in the control group were given Guided Imagery exercises as to reduce their depression signs and symptoms.

\section{EXPERIMENTAL DETAILS}

Guided Imagery was recorded on CD and consisted of 10 Guided Imagery scripts from natural scenes for 10 sessions including scenes of beautiful gardens, sea shores, hills and mountains, rice fields and lagoons which involved all the senses. Each session of Guided Imagery lasted about 20 min.

Subjects in the experimental group were asked to practice Guided Imagery in group three times a week for 4 weeks of treatment period in a comfortable place and minimum stimulus. The sessions began by subjects taking slow deep breathing exercise for relaxation and then they would listen to and imagine relaxing scenes from the script. The sessions ended by subjects taking slow deep breathing exercise. Subjects were requested to explain about their experiences and difficulties during the imaging process. After the Guided Imagery exercises were finished, both groups took a post test. Subject's data were collected from August to September 2014.

\section{STATISTICAL ANALYSIS}

Data were grouped and managed using SPSS version 13 for Windows and divided into frequency, mean, standard deviation and $p$ values represented in the tables. Univariate and bivariate analysis were administered to describe the mean score of depression for both groups before and after the intervention using the pair $t$ test. Independent $t$ test were administered to compare the mean scores of depression between the experimental and control groups.

\section{RESULT}

\section{DEMOGRAPHIC DATA}

The subjects were men aged from 45 to 70 years. The mean age and standard deviation of the experimental group was $56.31 \pm 6.53$ years and $53.94 \pm 6.29$ years for the control group. Education and occupations of subjects all described in Table 1.

The homogeneity testing of depression mean score before intervention were equal between the experimental and control groups $(p=0.457)$ (Table 2$)$.

\section{EFFECT OF GUIDED IMAGERY ON DEPRESSION}

Pair sample t-test was administered to compare the effect of Guided Imagery on depression in both groups, described in Table 3.

The mean difference scores showed that both groups' depression level decreased. However, the experimental

TABLE 1. Education and occupation characteristics of the subjects

\begin{tabular}{|c|c|c|c|c|c|}
\hline \multirow[t]{2}{*}{ Variables } & \multirow[t]{2}{*}{ Categories } & \multicolumn{2}{|c|}{$\begin{array}{l}\text { Experimental Group } \\
\qquad(\mathrm{n}=16)\end{array}$} & \multicolumn{2}{|c|}{$\begin{array}{l}\text { Control Group } \\
\qquad(\mathrm{n}=16)\end{array}$} \\
\hline & & $\mathrm{N}$ & $\%$ & $\mathrm{~N}$ & $\%$ \\
\hline \multirow{3}{*}{ Education } & High school & 5 & 31.3 & 4 & 25.0 \\
\hline & Undergraduate & 4 & 25.1 & 6 & 37.5 \\
\hline & Postgraduate & 7 & 43.8 & 6 & 37.5 \\
\hline \multirow{3}{*}{ Occupations } & Government officials & 10 & 62.5 & 8 & 50.0 \\
\hline & Private businessmen & 6 & 37.5 & 5 & 31.25 \\
\hline & Parliament members & 0 & 0 & 3 & 18.75 \\
\hline
\end{tabular}

TABLE 2. Homogeneity between experimental and control groups prior to intervention

\begin{tabular}{lcccc}
\hline Group & $\mathrm{N}$ & Mean $(\mathrm{X} \pm \mathrm{SD})$ & Scores min- max & P values \\
\hline Experimental & 16 & $1.63 \pm 6.42$ & $11-30$ & 0.457 \\
Control & 16 & $18.00 \pm 5.77$ & $10-30$ & \\
\hline
\end{tabular}

Significance $(p \leq 0.05)$ 
TABLE 3. Effect of Guided Imagery between the experimental and the control groups prior to and following intervention

\begin{tabular}{lccccc}
\hline Groups & Intervention & $n$ & $\begin{array}{c}\text { Mean } \\
\left(\mathrm{X}_{ \pm} \mathrm{SD}\right)\end{array}$ & $\begin{array}{c}\text { Mean differences } \\
(\mathrm{X} \pm \mathrm{SD})\end{array}$ & P value \\
\hline \multirow{2}{*}{ Experimental } & Before & 16 & $19.63 \pm 6.42$ & $12.19 \pm 7.42$ & 0.000 \\
& After & 16 & $7.44 \pm 4.04$ & & \\
\multirow{2}{*}{ Control } & Before & 16 & $18.00 \pm 5.77$ & $7.06+6.07$ & 0.000 \\
\hline
\end{tabular}

Significance $(p \leq 0.05)$

group's depression level decreased greater than that of control group. Table 3 shows that the experiment's mean is $12.19 \pm 7.42$, while the control group's is $7.06 \pm 6.07$ ( $p$ value $=0.000$ of $95 \% \mathrm{CI}$ ).

The independent sample t-test result showed a significant difference between the experimental and the control groups $(p=0,041$ of $95 \% \mathrm{CI})$. The results showed that the mean differences in the experimental group was higher than the control group before and after intervention and it can be concluded that Guided Imagery reduced depression among the inmates.

\section{DISCUSSION}

Subjects from both groups were men and they had equal mean scores of depression before intervention. They felt depressed and shocked while adapting quickly to prison life. They needed to adapt to new culture which was very different from their own culture and also they had to determine how to pass the time while in prison. However male prisoners fear deteriorating because of imprisonment. In reality they may get less or even lose contact with their family. As husbands they should be responsible for their families and they felt guilty that they neglected their families due to imprisonment. This condition was associated with the study by Turney et al. (2012) who stated that male inmates were unable to achieve economical goals for themselves and their family during incarceration. This report also supported a study by Ahmad and Mazlan, (2014) which stated that stress was a predictor for depression for $34 \%$ of male prisoners and $20 \%$ of female prisoners.

After Guided Imagery was administered for 10 sessions, it was found that the experimental group had a higher significant reduction in depression signs and symptoms than the control group. During Guided Imagery, subjects from the experimental group were asked to listen and imagine scenes of beautiful, relaxing, peaceful situations from recordings to stimulate a response from senses such as sight, sound, smell, touch and taste to the situation. They reported feeling more relaxed, having fewer depression symptoms and experiencing fewer from sleep disturbances and increased well being.

Mental imagery as mind-body therapy theory postulated, demonstrated the ability to produce physiological changes including improved cardiac-vagal tone and cardiovascular function, improved neuro- endocrine, immune and inflammatory responses and increased homeostasis. Mental imagery was effective in reducing depression symptoms, insomnia, anxiety, post traumatic stress, irritable bowel syndrome, diabetes and hypertension (Taylor et al. 2010).

The result of this study aligns with another investigation conducted by Vakylabad et al. (2013) which found that the Guided Imagery effectively reduced depression levels of elders. Likewise, a study by Menzies et al. (2014) showed that Guided Imagery increased self-efficacy, decreased stress, fatigue, pain and depression in women with fibromyalgia. Research conducted by Bigham et al. (2014) stated that Guided Imagery was used as a therapeutic process as by modifying behavior to produce relaxation also decreased anxiety and depression and control negative thinking.

The findings from this study also related to the investigation by Zafra et al. (2015) who stated that Guided Imagery relaxation reduces levels of pain and depression in patients with fibromyalgia. The use of Guided Imagery is effective in reducing depression among prisoner's corruptors and can be implemented to others Correctional Institutions or prisons. Nevertheless, the control group reported a decreased level of depression without the use of Guided Imagery and only participated in activities such as reading the Holy Book (Al Quran), which encourages spiritual well being; entertainment activities such as jogging and reading books at the library. These activities have advantages such as motivating the inmates to build spiritual optimism to accept reality and look forward. However, most of these inmates have relatively high levels of education and they are of matured age, so that their perception of life should also be well established to deal with problems related to imprisonment.

\section{CONCLUSION}

Health care providers have treated their signs and symptom of depression among prisoners convicted of corruption using pharmacological and spiritual strategies, but psychological treatment was not given to reduce depression among them. Consecutively, Guided Imagery is a powerful, simple and economic intervention to reduce the depression symptoms. The result of this study showed that the experimental group experienced a lower level of depression than the control group. This study 
can be applied to other correctional institutions to reduce depression among prison inmates.

It is recommended that further studies be done to explore the effectiveness of Guided Imagery on depression among prison inmates.

\section{ACKNOWLEGDEMENTS}

We would like to thank the prisoners at Correctional Institution Class I Sukamiskin Bandung who participated in this study. This study was financial supported by Bandung Polytechnic, Ministry of Health Indonesia.

\section{REFERENCES}

Ahmad, A. \& Mazlan, N.H. 2014. Stress and depression: A comparison study between men and women inmates in Peninsular Malaysia. International Journal of Humanities and Social Sciences 4(2): 153-159.

Alan, J., Burmas, M., Preen, D. \& Pfaff, J. 2011. Inpatient hospital use in the first year after release from prison: A Western Australian population-based record linked study. Aust N.Z. J. Public Health 35(3): 264-269.

Beck, A.T., Steer, R.A. \& Carbin, M.G. 1988. Psychometric properties of the Beck depression inventory: Twenty-five years of evaluation. Clinical Psychology Review 8(1): 77-100.

Bigham, E., McDanel, L., Luciano, I. \& Lopez, G.S. 2014. Effect of a brief Guided Imagery on stress. Biofeedback 42(1): 28-35.

Blackwell, S.E. \& Holmes, E.A. 2010. A modifying interpretation and imagination in clinical depression: A single case series using cognitive bias modification. App. Cogn. Psychol. 24(3): 338-350.

Dick, H. \& Butt, S. 2013. Is Indonesia as Corrupt and Most People Believe and Is Getting Worse? PolicyPaper. Center for Indonesia Law, Islam and Society http://www.law.unimelb. edu.au/cillis/research/center-publications/cillis-policy-paper. Accessed on 10 May 2014.

Directorate General Justice, Freedom, and Security, 2010. The Study to Examine the Links between Organized Crime and Corruption. European Commission.

Dong, B., Dulleck, U. \& Torgler, B. 2012. Corruption: A Review of Contemporary Research. Bergen.

Dye, M.H. 2010. Deprivation, importation and Prison suicide: Combined effect of Institutional condition inmate composition. Journal of Criminal Justice 38: 796-806.

Heyes, S.B., Lau, J.Y.F. \& Holmes, E.A. 2013. Mental imagery, emotion and psychopathology across child and adolescent development. Developmental Cognitive Neuroscience 5: 119-133.

Holmes, E.A. \& Mathews, A. 2010. Mental imagery in emotion and emotion disorders. Clin. Psychol. Rev. 30: 349-362.

Hughes, L.D. 2012. Psychosocial treatments for depression in UK Criminal Justice - A review of the evidence. Scottish Universities Medical Journal (Dundee) Electronically Published SUMJ 008.

Huisman, W. \& VandeWalle, G. 2010. The criminology of corruption. In The Good Cause: Theoretical Perspectives on Corruption, edited by De Graaf, G., Von Maravic, P. \& Wagenaar, P. Leverkusen: Barbara Budrich Publishing. pp. 132-169.
Lin, M.F., Hsu, M.C., Chang, H.J., Hsu, Y.Y., Chou, M.H. \& Crawford, P. 2010. Pivotal moments and changes in the Bonny method of Guided Imagery and music for patients with depression. J. Clin. Nurs.19(7-8): 1139-1148.

Math, S.B., Murthy, P., Parthasnthy, R., Kumar, C.N. \& Madhusudhan, S. 2011. Minds Imprisoned: Mental Health Care in Prisons. National Institute of Mental Health Neuro Sciences., Bangalore, India.

Menzies, V., Lyon, D.E., Elswick, Jr. R.K., Nancy, L.Mc. \& Gray, D.P. 2014. Effect of guided imagery on biobehavioral factors in women with fibromyalgia. Journal of Behavior Medicine 37(1): 70-80.

Ministry of Foreign Affairs of the Netherlands and Ministry Justice of Romania. 2015. Offender on causes and consequences of corruption: A study on corruption in Romania.

Morina, N., Deeprose, C., Pusowski, C., Schmid, M. \& Holmes, E.A. 2011. Prospective mental imagery in patients with major depressive disorders or anxiety disorders. J. Anxiety Disord. 25: 1032-1037.

Pictet, A., Coughtrey, A.E. \& Mathew, A. 2011. Fishing for happiness: The effects of generating positive imagery on mood and behavior. Journal Behav. Res. Ther. 49: 885-891.

Quah, J.S.T. 2011. Combating corruption in Asian countries: What lessons have we learnt? Public Adminisration and Policy16(1): 15-34.

Tavit, M. 2010. Why do people engage in corruption? The case of Estonia. Social Forces 88(3): 1257-1280.

Taylor, A.G., Goehler, L.E., Galper, D.I., Innes, K.E. \& Bourguignon, C. 2010. Top-down and bottom-up mechanisms in mind-body medicine: Development of an integrative framework for psychological research. EXPLORE: The Journal of Science and Healing 6(1): 29-41.

Turney, K., Wildeman, C. \& Schinittker, J. 2012. As father and felons: Explaining the effect of current and recent incarceration on major depression. J. Health Soc. Behav. 53(4): 465-481.

Vakilabad, B.M., Fallahi, K.M., Saiyed, B.M.S. \& Mohamad, A.H. 2013. The effect of mind education by imagery on depression of elders. Iranian Journal of Nursing Research (7)27: 10-17.

Weiten, W., Dunn, D.S. \& Hammer, E.Y. 2011. Psychology Applied to Modern Life: Adjustment in the 21st Century. Belmont: Wadsworth.

Zafra, O., Dolores, M., Hernandez, G.L. \& Del Valle, M.G. 2015. Effectiveness of Guided Imagery on levels of pain and depression in patients diagnosed with fibromyalgia. Holistic Nursing Practice 29(1): 13-21.

Nursing Department, Bandung Polytechnic

Ministry of Health Indonesia

Indonesia

*Corresponding author; email: nurgiwiatiendeh@gmail.com

Received: 24 February 2015

Accepted: 19 June 2015 